sages that enable us to work together and supporting each other in one voice.

Garcia: "One ALA" means that we are all members of one association. An association that values the contributions of all of our members. An association where all voices are heard. ACRL and our other divisions and roundtables are critically important to the success of ALA. As your president, I would work for more open and frequent communication with division leadership to ensure that our goals and priorities are in alignment associationwide. As we advance together to a better future for ALA, I want to make sure the knowledge and experience of successful member engagement in our divisions and roundtables help inform how we move forward. We should all be working together learning from one another to make ALA a more sustainable association.

For more information about my candidacy please visit:

- Website: www.edforala.com

- Twitter: https://twitter.com/edgarcia401

- FB: https://www.facebook.com/edforala

- \#EdforALA
Pelayo-Lozada: "One ALA" to me indicates we all work together towards the same goal and share ALA's mission "... to enhance learning and ensure access to information for all." There are so many ways to achieve this, through our divisions, through our core values and committees, and through our round tables. I see "One ALA" as all of these groups, bringing unique perspectives and expertise to promoting this shared mission. By supporting one another and leading together, we are stronger working towards this goal. Our divisions do this with opportunities for their members, such as conferences and publishing opportunities. Our divisions, such as ACRL, also do this through progressive training for their members in areas such as EDI, creating opportunities for their members to remain not just in ACRL but in and engaged with the entire association. I see all areas of ALA working collaboratively on cross issues, and supporting and promoting each other's areas of singular interest and common interest, creating a true "One ALA." $\approx$

\title{
ACRL members running for ALA Council in the spring 2021 election
}

The following ACRL members are either nominated or petition candidates for ALA councilor. ACRL members are encouraged to vote for these candidates to increase ACRL's voice in ALA affairs.

Kimberley Bugg, Associate Library Director, AUC Woodruff Library

Elizabeth Call, University Archivist, Rochester Institute of Technology

Fannie M. Cox, Outreach and Reference Librarian, Associate Professor, University of Louisville Libraries

Roberto C. Delgadillo, Student Services Librarian, Student Services Department, Peter J. Shields Library, University of CaliforniaDavis

Bob Diaz, Associate Librarian and Archivist, University of Arizona Libraries

Jina DuVernay, Collection Development Archivist for African American Collections,
Stuart A. Rose Manuscript, Archives, and Rare Book Library at Emory University

Linda Marie Golian-Lui, Associate Dean Library Services, Director of EAST, and Librarian Professor, Kennesaw State University

Mario M. Gonzalez, Executive Director, Passaic Public Library

Nicholas A. Lamb, Research and Learning Librarian, Cleary Gottlieb Steen and Hamilton LLP

Rodney Lippard, Director, Library and Center for Student Achievement, University of South Carolina-Aiken

Amanda Roper, Assistant Librarian 1, Chattanooga State Community College

Joan S. Weeks, Head Librarian Near East Section, Library of Congress/African and Middle Eastern Division

Christine Woods, Saint Leo University Regional Librarian Virginia, Mississippi, Texas, California, Saint Leo University 